\title{
FACTORS ASSOCIATED WITH THE REJECTION OF CHILD IMMUNIZATION: A SYSTEMATIC REVIEW
}

\author{
Yunia Nur Fadhillah, Rita Damayanti \\ Department of Health Promotion, Faculty of Public Health, Universitas Indonesia
}

\begin{abstract}
Background: Vaccine is an effective method to prevent infectious diseases and their complication. However, immunization coverage has declined drastically in some countries for some reasons. This study aimed to review sytematically the factors associated with the rejection of child immunization.

Subjects and Method: This was a systematic review conducted by searching published articles from database including PubMed, Wiley Online Library, JSTOR, SpringerLink, ScienceDirect, ProQuest, Scopus, ResearchGate, and Taylor\&Francis. The keywords were "immunization", "vaccination", "rejection", and "children". The inclusion criteria were English and open access. 176 articles were obtained by searching onlie database. After review process 8 articles were including in this review.

Result: Vaccination rejection was caused by incomplete information delivered by health workers and social media. Internal factors of parents were including age, experience, and education. External factor was socio-cultural. Misinformation about vaccines from anti-vaccine influenced parents.

Conclusion: Vaccination rejection is caused by incomplete information delivered by health workers and social media. Good health communication, performance of health workers, social media campaign can increase vaccine acceptance.
\end{abstract}

Keywords: immunization, vaccination, rejection, child.

\section{Correspondence:}

Yunia Nur Fadhillah. Masters Program in Health Promotion, Faculty of Public Health, Universitas Indonesia, Depok, West Java. Email: nianufa@gmail.com. Mobile: 0895344546702.

\section{BACKGROUND}

The world has been committed to efforts to prevent communicable diseases by immunization (vaccination). The goals of immunization are from the newborn baby to the adult age group. Immunization efforts are still considered an effective and efficient way to prevent the spread of diseases that can be prevented by vaccines and even eradicate the disease. In the United States, among children born during 1994-2013, vaccination will prevent around 322 million diseases, 21 million hospitalized, and 732,00o deaths, with direct cost savings of $\$ 295$ billion and $\$ 1.38$ trillion in total costs (Sobo, 2015).

The facts show that many countries on various continents refuse immunization. The SAGE Working Group concluded that vaccine hesitancy refers to late acceptance or rejecttion of vaccinations even though vaccination services are available (MacDonald et al., 2015). Adedokun et al. (2017) mentioned that in sub-Saharan Africa more than threequarters of children (76.3\%) were not fully immunized. About $83 \%$ of children of young mothers (15-24 years) and 94\% of those whose mothers are illiterate do not receive full immunization.

Berry et al. (2017) states that in Australia although $92 \%$ of children are fully vaccinated, there are an estimated $3.3 \%$ who refuse completely and choose or postpone vaccination (parents who object to vaccines). However, regional variations in vaccination objections are up to $14 \%$ of children. In Turkey around 33 parents compared with 99 parents (33\%) stated vaccine rejection (Topçu et al., 2019).

In the era of technological development, social relations related to the use of 
online media also contribute to social influence in the real environment. The results of Mavragani and Ochoa (2018) show that there is a significant positive correlation between disease incidence and online interest in most European countries (EU28). In addition, 'Anti-Vaccine' has a negative correlation with the percentage of immunizations worldwide from 2004 to 2016, that is, when online interest in the term 'Anti-Vaccine' is increasing, the percentage of immunization is reduced. This shows that the spread of information with internet-based media can influence decisions about vaccination. This systematic review provides scientific endeavors to the results of research on factors related to the rejection of children's immunization by parents. To guide this systematic review, the research questions were formulated as "What are the factors for refusing child immunezation by parents on various continents?"

The purposes of this systematic review are to investigate the comparison of vaccination rejection factors (immunization) in developed countries and developing countries on various continents and to discuss how research compares with related article.

\section{SUBJECTS AND METHOD}

\section{Study Design}

This was a systematic review study that reviews various articles that show the factors of rejection of vaccination of children by their parents in countries on various continents. Journal articles included in this research review were obtained from search results on e-Resources PubMed, wiley online library, JSTOR, SpringerLink, ScienceDirect, ProQuest, Scopus, Taylor \& Francis, using the keywords: immunization OR immunization OR vaccination AND children AND rejection.
}

\section{Inclusion and Exclusion Criteria}

Inclusion criteria of this articles:
1) Discussing about vaccinations (immunizations), children with incomplete vaccinations, vaccine refusals, vaccinations of children by parents, from countries representing the Asian Continent, Africa, America, Europe, Australia; 2) Published in peer-reviewed journals; 3) Written in English.

The exclusion criteria:

1) Discussing about adult or non-child vaccination; 2) Related to experimental research (except explicitly discussing vaccination rejection factors or doubts about vaccines); 3) Articles that are not peer reviewed or are not research articles.

\section{RESULTS}

Total journal findings through the identification process in several electronic journal databases are 1,652 journals from Springer Link, 2,220 journals from ScienceDirect, 3,200 journals from Wiley Online Library, 441 journals from JStor, 63 journals from Scopus, 1,781 journals from Prouest, and 42 journals. from Pubmed, 1,156 journals from Taylor and Francis. After screening 176 relevant journals were obtained. Furthermore, the feasibility selection is carried out based on the criteria according to which 8 journal articles were included. The process can be seen in Figure 1. Data Selection Flow Chart

A review of 8 journal articles met the criteria. These journals represent the continents of Asia, Africa, Europe, America and Australia. Asia is represented by India, Pakistan and Indonesia. Africa is represented by Nigeria, Rwandal, Ethiopia. Australia is for the Australian continent. The United States and Venezuela represent America continent. Turkey represents European continent. Details of these journals are set out in Table 1. 

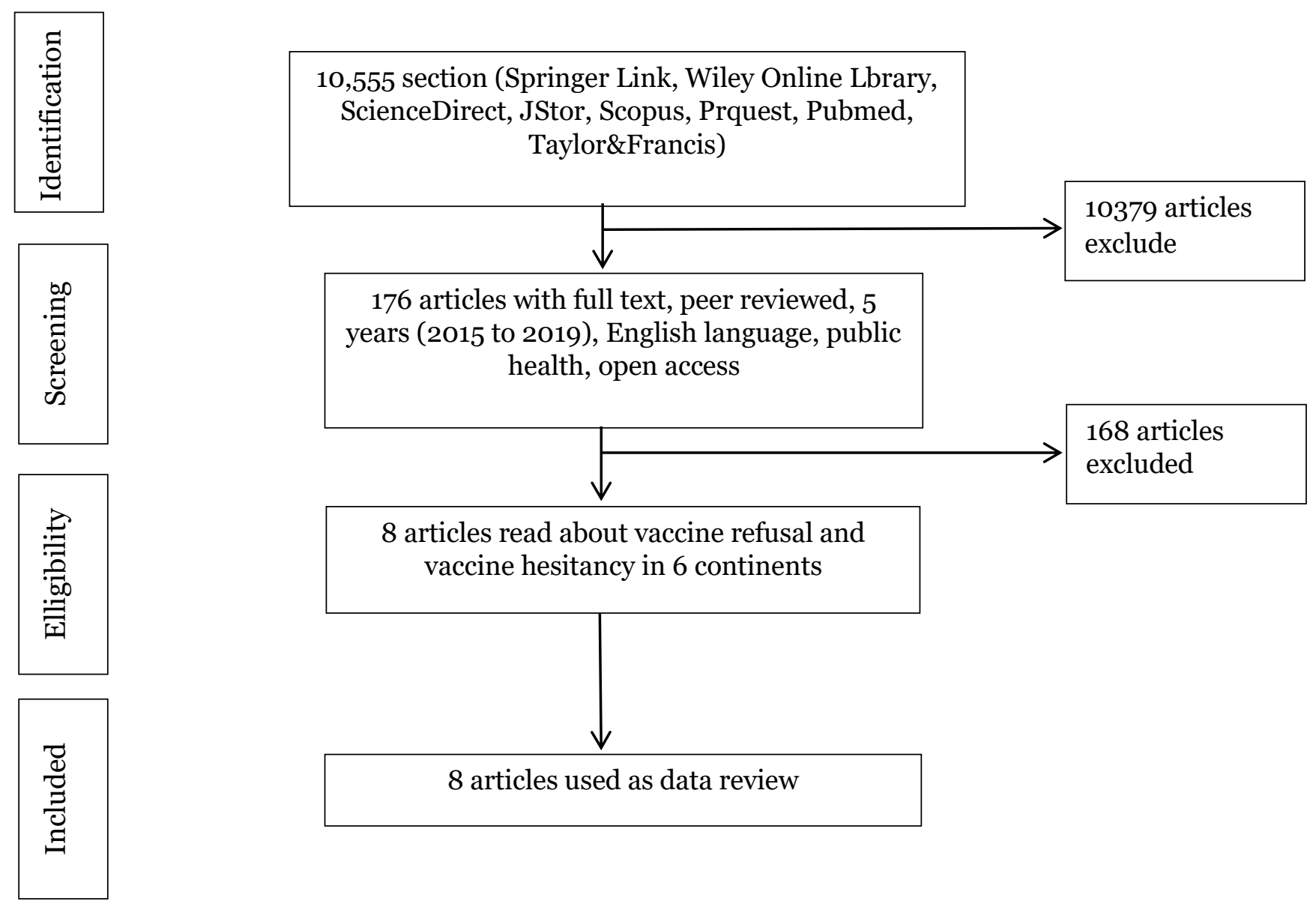

\section{Figure 1. PRISMA Flow Diagram}

\section{Anti-Vaccine Group}

In general, groups who reject vaccines are categorized into two groups. The first is a group called vaccine refusal. They are a society that strongly rejects vaccines. The second is known as vaccine hesitancy, which is not one hundred percent averse to vaccines and not so emphatically reject vaccines. The community in the second group may still be changed in their stance. Conversely, the first group is rather difficult to change their beliefs except through decisive action by the government.

Groups who know about the concept of group immunity (herd immunity) and who do not know the concept. But knowledge of the concept of group immunity is not enough to encourage parents to receive vaccines for their children. For parents who refuse vaccines, believe that with the immunity of the vaccinated group their children will be safe in group immunity and do not need to be vaccinated "hide in the herd" (Offit and Moser, 2009 in Attwel et al., 2017).

\section{Internal Factors of Parents}

In new mothers (first time pregnancy), lack of experience and information influences vaccination decisions. Research by Corben and Leask (2018) shows that young mothers in Australia are more likely to refuse vaccines three times. As found in Indonesia, beliefs are influenced by experiences about immunization both from oneself and others, as well as myths about immunization (Syiroj et al., 2019). Bad experiences will increase rejection of vaccination. Instead older mothers have gone through the rigors of caring for a sick child. Such mothers will appreciate any initiative designed to prevent the occurrence of childhood illness (Closser et al., 2016). 


\begin{tabular}{|c|c|c|c|c|c|}
\hline $\begin{array}{l}\text { No } \\
\text {. }\end{array}$ & Journal Articles & $\begin{array}{c}\text { Yea } \\
\mathbf{r}\end{array}$ & Location & Method & $\begin{array}{c}\text { Demonstration } \\
\text { focus }\end{array}$ \\
\hline 1. & $\begin{array}{l}\text { Chirumbolo S, Bjørklund G (2019) 'Evaluation of Childhood Vaccine } \\
\text { Refusal and Hesitancy Intentions in Turkey: Correspondence', The } \\
\text { Indian Journal of Pediatrics, 86(3): 315-317. doi: 10.1007/s12098- } \\
\text { o18-2772-3. }\end{array}$ & 2016 & Turkey, Europe & $\begin{array}{l}\text { Correspon } \\
\text { dence }\end{array}$ & $\begin{array}{l}\text { Parents with a Com- } \\
\text { plementary and Alter- } \\
\text { native Medicine } \\
\text { (CAM) presentation }\end{array}$ \\
\hline 2. & $\begin{array}{l}\text { Closser S, Rosenthal A, Maes K, Justice J, Cox K et al. (2016) ‘The } \\
\text { Global Context of Vaccine Refusal: Insights from a Systematic } \\
\text { Comparative Ethnography of the Global Polio Eradication } \\
\text { Initiative', Medical Anthropology Quarterly. Wiley Online Library, } \\
\text { 3o(3): 321-341. doi: } 10.1111 / \text { maq.12254. }\end{array}$ & 2012 & $\begin{array}{l}\text { Nepal, India, Pakis- } \\
\text { tan, Ethiopia, } \\
\text { Nigeria, Rwanda, } \\
\text { Angola }\end{array}$ & $\begin{array}{l}\text { Systematic Com- } \\
\text { parative } \\
\text { Ethnography }\end{array}$ & Toddler's mother \\
\hline 3. & $\begin{array}{l}\text { Adedokun ST, Uthman OA, Wiysonge CS (2017) 'Incomplete } \\
\text { childhood immunization in Nigeria: a multilevel analysis of indi- } \\
\text { vidual and contextual factors', BMC Public Health, 17(1): 236. doi: } \\
\text { 10.1186/s12889-017-4137-7. }\end{array}$ & 2013 & Nigeria & cross-sectional & Housewives \\
\hline 4. & $\begin{array}{l}\text { Burghouts J, Nogal BD, Uriepero A, Hermans PWM, de Ward JH, } \\
\text { Verhagen ML (2017) 'Childhood vaccine acceptance and refusal } \\
\text { among Warao Amerindian caregivers in Venezuela; A qualitative } \\
\text { approach', PLoS ONE, 12(1): 1-14. doi: 10.1371/journal.p- } \\
\text { one.0170227. }\end{array}$ & 2012 & Venezuela & Cualitative & Toddlers' parents \\
\hline 5. & $\begin{array}{l}\text { Attwell K, Leask J, Mayer SB, Rokkas P, Ward P (2017) ‘Vaccine } \\
\text { Rejecting Parents' Engagement With Expert Systems That Inform } \\
\text { Vaccination Programs', Journal of Bioethical Inquiry, 14(1): 65-76. } \\
\text { doi: 10.1007/s11673-016-9756-7. }\end{array}$ & $\begin{array}{c}2013 \\
- \\
2014\end{array}$ & Australia & Cualitative & Toddlers' parents \\
\hline 6. & $\begin{array}{l}\text { Sobo EJ (2015) 'Social Cultivation of Vaccine Refusal and Delay } \\
\text { among Waldorf (Steiner) School Parents', Medical Anthropology } \\
\text { Quarterly, 29(3): 381399. doi: 10.1111/maq.12214. }\end{array}$ & $\begin{array}{c}2011 \\
- \\
2013\end{array}$ & $\begin{array}{l}\text { United State (US) } \\
\text { Amerika }\end{array}$ & Cualitative & $\begin{array}{l}\text { Parents of elementary } \\
\text { school children }\end{array}$ \\
\hline 7. & $\begin{array}{l}\text { Gilmartin CE, Daley AJ, Leung L (2019) 'The hepatitis B birth-dose } \\
\text { immunisation: Exploring parental refusal', Australian and New } \\
\text { Zealand Journal of Obstetrics and Gynaecology, pp. 1-8. doi: 10.11- } \\
\text { 11/ajo.13008. }\end{array}$ & $\begin{array}{l}2016 \\
- \\
2017\end{array}$ & Australia & Cross sectional & Ibu postnatal \\
\hline 8. & $\begin{array}{l}\text { Syiroj ATR, Pardosi JF, Heywood AE (2019) 'Exploring parents' } \\
\text { reasons for incomplete childhood immunisation in Indonesia', } \\
\text { Vaccine. Elsevier Ltd, 37(43): 6486-6493. doi: 10.1016/j.vaccine.- } \\
\text { 2019.08.081. }\end{array}$ & $\begin{array}{c}2013 \\
- \\
2018\end{array}$ & Indonesia & Cualitative & Parents/babysitter \\
\hline
\end{tabular}

The $6^{\text {th }}$ International Conference on Public Health Best Western Premier Hotel, Solo, Indonesia, October 23-24, 2019|168 https://doi.org/10.26911/the6thicph-FP.02.07 
Based on Poltorak and colleagues' research in Sobo (2015) decisions are influenced "by personal history, birth experience and feeling control, family health history, understanding of their child's health in certain strengths and vulnerabilities, special involvement with health services, and through friendship and conversation with other people".

Research conducted by Closser et al. (2016) found that about $83 \%$ of children in Nigeria came from young mothers (1524 years), 94\% of these young mothers were illiterate and did not receive full immunization. Similar to what happened in Venezuela, Amerindian populations found vaccine refusal to occur in parents with low education (primary school) (Burghouts et al., 2017).

Children of mothers with no education and graduates of basic education have a higher chance of being fully immunized compared to children of mothers with secondary or higher education. When maternal education levels increase, the likelihood of having children who are not fully immunized decreases so that children of mothers with secondary or higher education have the least chance of not being fully immunized when compared to children whose mothers have primary education or no education. Education has a profound effect on maternal health seeking behavior that includes child immunezation.

Conversely, in America which is a developed country, it turns out that shows a different fact. Parents with higher education do not make the opportunity to vaccinate even higher. It was found parents who have never vaccinated, who started but stopped, who are currently delaying or vaccinating in part, and exprocrastinators now are restarting. Plus some other influences that influence acceptance of vaccination, such as the influence of anti-vaccine social groups (Sobo, 2015).

\section{Social Environment}

Receiving vaccinations is positive when referring to the right sources giving the right information. But it will be a new problem if the information published is not from a competent and correct source. Both in developed and developing countries, the social environment can affect vaccination decisions.

In Australia, relations with the antivaccine community to create social ties increase the chances of vaccine rejection (Sobo, 2015). In Nigeria, intra-country and intra-community correlations indicate that the completeness of child immunization is related to each country and community level factor. The social environment which has a low level of immunization affects the decision of the mother to give immunizations to her child, and vice versa (Adedokun et al., 2017). In Indonesia the social support of the people closest also influences immunization decisions (Syiroj et al., 2019).

In addition to direct social relations, social relations on online media also have an influence on the decision to reject the vaccine. In an era of rapid media development, this gives room for rapid exchange of information. Almost every country in the world currently uses new media (internet-based). Social media and blogs have important effects on parents in decisions about vaccines. Thus, vaccine decision making is a very social process (Chirumbolo et al., 2017).

\section{Political economy}

In Nigeria, around 9 out of every 10 children living in the most economically disadvantaged communities and states have not been fully immunized (Adedokun et al., 2017). In countries with low economic levels, immunization receipts obtained are also low. Meeting basic 
needs that are difficult to fulfill prevents the receipt of immunizations that are considered not basic needs. Another case in countries with high economic levels, the refusal is based on suspicion in the political economy, assuming that there is cooperation between the government, the profession and the pharmaceutical industry that uses vaccines as a way to generate large profits (AttwellK et al., 2017). In Indonesia, one of the factors for vaccine refusal is due to distrust of the government, and is also linked to western political economy (Syiroj et al., 2019). suspicion of the western political economy is also found in Pakistan (Closser et al., 2016).

\section{Cultural and Religious Influences}

Religiosity factor influences the decision of vaccine acceptance and rejection. An example is the belief in the concept of being healthy and sick that being healthy and sick is a gift from God and God has provided a way of treating a disease. There are also those who think that giving medicine before illness is considered as shirk (denying God). The issue of raw material for making vaccines is still in doubt in terms of safety and halality.

Closser et al. (2016) suggested that in Nigeria, information branding with the concept of religion influences the decision to reject vaccine. Political history that opposes the western concept increasingly supports vaccine refusal. In Pakistan, Malaysia, Indonesia and Nigeria, the issue of halalism, myths, and the presumption of vaccines are used as magic weapons for political power (Closser et al., 2016; Syiroj, 2019). Distrust of Western medicine because they see it from a narrow perspective (with a pharmaceutical company relationship) and not holistic.

The application of natural, tradetional and alternative medicine and including believing in homeopathic medicine correlates with doubts about vaccines. In Italy it was found that the use of complementary and alternative medicine (CAM) showed a significant correlation with vaccine rejection. They believe that only by maintaining a clean and healthy lifestyle, antibiotics and proper nutrition are enough to prevent disease infections so they no longer need to vaccinate (Attwell et al., 2017; Chirumbolo, and Bjørklund, 2019). Treatment seeking behavior in traditional medicine is also found in the Warao Amerindian region of Venezuela (Burghouts et al., 2017).

\section{Vaccine Health and Safety Service} System

The possibility of not being fully immunized is reduced in children whose mothers visit antenatal clinics, are given in health facilities and live in urban areas. Children whose mothers have difficulty going to health facilities have a greater chance of getting incomplete immunizations. Poor health services reduce trust in the health system created by the government and influence trust in immunization. The health system built by the government is important as a commitment of the state to provide the best service for its people.

Submission of good and correct information about vaccines in appropriate ways, and trust in health personnel influences acceptance of vaccines (Gilmartin et al., 2019). In Nigeria, where health services are poor, interpersonal health personnel are also low, causing people to feel intimidated to receive vaccines and feel humiliated, making high resistance to immunization. Whereas in India, the provision of services from other programs such as education and nutrition, free care, provision of supplements as a whole with the provision of vaccines can increase acceptance of immunization (Closser et al., 2016). 
Vaccine safety issues, related to the manufacturing material to the output effect that vaccines cause autism, are a factor in rejection of vaccines. In Indonesia and Malaysia various negative myths related to immunization include stating that immunization can cause mental disability, paralysis, often illness, autism, until death (Syiroj et al., 2019). In America, parents consider vaccines to be highly toxic, causing allergies, disabilities to brain damage (Sobo, 2015). In Australia for new mothers, lack of experience and lack of information about vaccines increases concern about side effects, safety, and effectiveness of vaccines (Corben and Leask, 2018). Similarly, in Turkey, parents who believe that dangerous vaccines are a decisive factor for vaccine rejection (Chirumbolo and Bjørklund, 2019).

Rejection of HBV vaccine in neonatal occurs in Australia because of doubt about the safety of vaccines for newborns because they think babies are still vulnerable to receive the vaccine. In addition, parents also assume the baby has a natural immunity that will continue to form, so giving a vaccine will be very excessive for infant immunity (Gilmartin et al., 2019).

There is a mention of the terms vaccination and immunization with the same meaning. In countries in the European continent, America and Australia, what is used is the mention of vaccination, while the continent countries of Africa and Asia more often use the mention of immunization. Vaccine safety and information dissemination through online media are common vaccine rejection factors in all countries. Utilization of the internet is inevitable in the era of technological advancements with the rapid dissemination of information. The problem of low health services, access to ser- vices, and the economy are common factors found in developing countries. Political factors of suspicion in the conspiracy of the vaccine industry, government and health professionals are the main factors that emerge in developed countries.

The Immunization Program is one of the most effective health programs in health development especially to prevent morbidity, disability and death caused by diseases that can be prevented by immunization. Submitting true and correct information about vaccinations plays an important role in receiving vaccines. These factors are based on good health communication including interpersonal health personnel and activities in the mass media such as social media (Schiavo and Renata, 2014).

Social media can be used as a counter to anti-vaccines by delivering provaccine messages that show the benefits of vaccination for immunity and the analogy of vaccine "side effects" such as fever as an indication of bodily reinforcement as the opinion that child illness increases natural immunity. Appropriate public relations strategies such as using important figures will be effective against receiving vaccines (Schiavo and Renata, 2014). In Pakistan, on average they use the president's daughters as ambassadors of the mass media vaccination and treatment campaign (Closser et al., 2016).

\section{REFERENCES}

Adedokun ST, Uthman OA, Wiysonge CS (2017). Incomplete childhood immunization in Nigeria: A multilevel analysis of individual and contextual factors. BMC Public Health 17. doi:10.1186/s12889-017-4137-7

Fahmi AU (2006). Imunisasi: mengapa perlu? (Immunization: why is it 
necessary?). Jakarta: PT Kompas Media Nusantara.

Attwell K, Leask J, Mayer SB, Rokkas P, Ward $P$ (2017). Vaccine rejecting parents engagement with expert systems that inform vaccination programs, Journal of Bioethical Inquiry, 14(1): 65-76. doi: 10.1007/s11673-016-9756-7.

Berry NJ, Henry A, Leask J (2017). When parents won't vaccinate their children: A qualitative investigation of Australian primary care providers experiences. BMC Pediatrics 17. doi:10.1186/s12887-017-0783-2

Burghouts J, Nogal BD, Uriepero A, Hermans PWM, de Ward JH, Verhagen ML (2017) Childhood vaccine acceptance and refusal among Warao Amerindian caregivers in Venezuela; A qualitative approach, PLoS ONE, 12(1): 1-14. doi: 10.1371/journal.pone.0170227.

Chirumbolo S and Bjørklund G (2019). Evaluation of childhood vaccine refusal and hesitancy intentions in Turkey: correspondence, The Indian Journal of Pediatrics, 86(3): 315-317. doi: 10.1007/s12098-018-2772-3.

Closser S, Rosenthal A, Maes K, Justice J, Cox K, Omidian PA, Mohammed IZ et al. (2016). The global context of vaccine refusal: insights from a systematic comparative ethnography of the global polio eradication initiative, medical anthropology quarterly. Wiley Online Library, 30(3): 321-341. doi: 10.1111/maq.12254.

Corben P, Leask J (2018). Vaccination hesitancy in the antenatal period: a cross-sectional survey, BMC Public Health, 18(1): 566. doi: 10.1186/s12889-018-5389-6.
Gilmartin CE, Daley AJ, Leung, L (2019). The hepatitis B birth-dose immunization: Exploring parental refusal, Australian and New Zealand Journal of Obstetrics and Gynaecology, 1-8. doi: 10.1111/aj0.13008 .

MacDonald NE (2015). Vaccine hesitancy: Definition, scope and determinants, Vaccine, 33(34): 4161-4164. doi: 10.1016/j.vaccine.2015.04.036.

Mathilda A (2009). Kelengkapan imunisasi (completeness of immunezation). Depok: Fakultas Kedokteran Universitas Indonesia.

Mavragani A, Ochoa G (2018). The internet and the anti-vaccine movement: tracking the $2017 \mathrm{eu}$ measles outbreak', Big Data and Cognitive Computing, 2(1): 2. doi: 10.3390/bdcc2010002.

Ndoen E (2018). Krisis kepercayaan penyebab cakupan imunisasi anak Indonesia menurun 5 tahun terakhir (The crisis of confidence causes the immunization coverage of Indonesian children to decrease in the last 5 years). Retrieved from https://theconversation.com/krisis-kepercayaan-penyebab-cakupan-imunisasi-anak-indonesiamenurun-5-tahun-terakhir107900

Schiavo R (2014). Health communication second edition: from theory to practice. United States of America.

Syiroj ATR, Pardosi JF, Heywood AE (2019). Exploring parents reasons for incomplete childhood immunisation in Indonesia', Vaccine. Elsevier Ltd, 37(43): 6486-6493. doi:10.1016/j.vaccine.2019.08.081.

Sobo EJ (2015). Social cultivation of vaccine refusal and delay among wal- 
dorf (steiner) school parents, Medical Anthropology Quarterly, 29(3): 381-399. doi: 10.1111/maq.12214.

Sulistiyani P (2017). Gambaran penolakan masyarakat terhadap imuni- sasi dasar lengkap bagi balita (description of community rejecttion of complete basic immunization for toddlers). Jurnal Kesehatan Masyarakat, 5(5): 1081-1091. 